\title{
Gas-Phase Reactivity Studies of Small Molybdenum Cluster lons with Dimethyl Disulfide
}

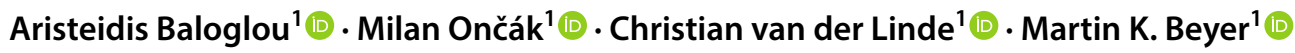

Published online: 27 November 2017

(c) The Author(s) 2018. This article is an open access publication

\begin{abstract}
Molybdenum sulfide is a potent hydrogen evolution catalyst, and is discussed as a replacement of platinum in large-scale electrochemical hydrogen production. To learn more about the elementary steps of $\mathrm{MoS}_{2}$ production by sputtering in the presence of dimethyl disulfide (DMDS), the reactions of $\mathrm{Mo}_{\mathrm{x}}^{+}, \mathrm{x}=1-3$, with DMDS are studied by Fourier transform ion cyclotron resonance mass spectrometry and density functional theory calculations. A rich variety of products composed of molybdenum, sulfur, carbon and hydrogen was observed. $\mathrm{Mo}_{\mathrm{x}} \mathrm{S}_{\mathrm{y}}{ }^{+}$species are formed in the first reaction step, together with products containing carbon and hydrogen. The calculations indicate that the strong Mo-S bonds are formed preferentially, followed by Mo-C bonds. Hydrogen is exclusively bound to carbon atoms, i.e. no insertion of a molybdenum atom into a $\mathrm{C}-\mathrm{H}$ bond is observed. The reactions are efficient and highly exothermic, explaining the rich chemistry observed in the experiment.
\end{abstract}

Keywords Gas-phase ion chemistry $\cdot$ Molybdenum cluster $\cdot$ Dimethyl disulfide $\cdot$ Sulfidation

\section{Introduction}

The environmentally benign generation of hydrogen via water electrolysis plays a key role in a future hydrogen economy. The most efficient catalyst for the hydrogen evolution reaction (HER) is platinum, but the available supplies of this element are not sufficient to meet the expected demand for large-scale hydrogen production. Molybdenum sulfide $\left(\mathrm{MoS}_{2}\right)$ based catalysts have the potential to replace platinum as a HER catalyst in electrochemical water splitting [1-7]. The material is also discussed as a catalyst for methanol synthesis from carbon dioxide and molecular hydrogen [8,9]. A better understanding of the reaction mechanisms contributes to the targeted optimization of the catalysts.

In industry, $\mathrm{MoS}_{2}$-based catalysts are widely used e.g. in hydrotreating of refined petroleum products [10-13], as well as a lubricant [14]. For the sulfidation of molybdenum,

Electronic supplementary material The online version of this article (https://doi.org/10.1007/s11244-017-0864-3) contains supplementary material, which is available to authorized users.

Martin K. Beyer

martin.beyer@uibk.ac.at

1 Institut für Ionenphysik und Angewandte Physik, Universität Innsbruck, Technikerstraße 25, 6020 Innsbruck, Austria various sulfur agents may be used, such as hydrogen sulfide $\left(\mathrm{H}_{2} \mathrm{~S}\right)$ or organosulfide compounds like dimethyl disulfide (DMDS) [15]. In a previous study the tendency of carbon to become incorporated into $\mathrm{MoS}_{2}$ nanoparticles synthesized from a metallic Mo precursor was investigated [16], with the main focus lying on the possible incorporation of carbon during the sulfidation with organosulfides, namely DMDS and dimethyl sulfide (DMS). Scanning tunneling microscopy showed that the size and shape of the resulting $\mathrm{MoS}_{2}$ clusters were affected by the choice of the sulfiding agent [16]. X-ray photoelectron spectroscopy revealed that when $\mathrm{H}_{2} \mathrm{~S}$ or DMDS was used as a sulfur agent, no carbon was incorporated inside or on the surface of the nanoclusters [16]. However, when using DMS instead, incomplete sulfidation led to some carbon species on poorly crystalline $\mathrm{MoS}_{2}$ phases of non-carbide nature, which disappeared upon annealing [16]. The deficiency of carbon after sulfidation could be explained by DMDS decomposition into DMS and $\mathrm{H}_{2} \mathrm{~S}$ in the presence of $\mathrm{H}_{2}$, as reported by Texier et al. [15]. In the absence of hydrogen, direct extraction of sulfur from DMDS with the formation of DMS as a byproduct has the same effect. DFT calculations were used to investigate the stability of different carbon species $\left(\mathrm{C}, \mathrm{CH}, \mathrm{CH}_{2}\right)$ incorporated into $\mathrm{MoS}_{2}$ [16]. The calculations showed that, both for S-edge and Mo-edge, the stability of the substituted species increases from $\mathrm{C}$ via $\mathrm{CH}$ to $\mathrm{CH}_{2}$ [16]. Further quantum chemical 
studies addressed $\mathrm{Mo}_{10} \mathrm{~S}_{x}$ species as model systems of planar molybdenum sulfide clusters [17], determined the most stable composition of $\mathrm{Mo}_{n} \mathrm{~S}_{m}$ species [18], or investigated hydrogen evolution from water mediated by $\mathrm{Mo}_{3} \mathrm{~S}_{4}{ }^{-}$[19].

In the gas phase, $\mathrm{MoX}_{n}{ }^{+}, \mathrm{X}=\mathrm{O}, \mathrm{S}, n=1-3$, have been studied with a combination of experiment and theory [20] by Schwarz and co-workers. Very recently, the reactions of molybdenum monoxide and dioxide cations with ethanol were addressed by the same group [21, 22]. Structure and thermochemistry of $\mathrm{MoS}_{\mathrm{x}}{ }^{+}$was addressed by Schwarz, Armentrout and co-workers using guided ion beam experiments and Fourier transform ion cyclotron resonance (FTICR) mass spectrometry in combination with quantum chemistry [23]. Guided ion beam experiments also yielded a wealth of thermochemical data on $\mathrm{MoO}_{\mathrm{x}}{ }^{+}$species interacting with $\mathrm{CO}$ and $\mathrm{CO}_{2}$ [24, 25]. Fielicke and co-workers studied the effect of molybdenum doping on the reactivity of metal and metal oxide clusters [26, 27]. Bohme and coworkers established that a gas-phase $\mathrm{Mo}\left(\mathrm{C}_{60}\right)_{4}{ }^{+}$complex can be formed in a flow reactor [28]. The same group studied the reactions of $\mathrm{Mo}^{+}$with heavy water [29], carbon disulfide [30], $\mathrm{O}_{2}$ [31] and $\mathrm{N}_{2} \mathrm{O}$ [32] as part of a large-scale investigations of periodic trends. Although lying in the thermodynamic window, $\mathrm{Mo}^{+}$does not catalyze the reduction of $\mathrm{N}_{2} \mathrm{O}$ by $\mathrm{CO}$ [33].

In this work, the formation of $\mathrm{Mo}_{\mathrm{x}} \mathrm{S}_{\mathrm{y}}{ }^{+}$clusters from $\mathrm{Mo}_{n}{ }^{+}$ and DMDS is studied to understand the formation of these clusters. For this task an FT-ICR mass spectrometer is used, as it is an excellent tool for the examination of ion-molecule reactions in the gas-phase [34-36], including catalytic cycles [37-39]. Experiments are complemented by quantum chemical calculations of reactant and product species to test whether the observed product ions are energetically accessible.

\section{Experimental Section and Calculations}

The reactivity measurements are performed on a modified Bruker/Spectrospin CMS47X FT-ICR mass spectrometer, equipped with a $4.7 \mathrm{~T}$ superconducting magnet and an Apex III data station [40, 41]. The ions are generated in a laser vaporization source [42-44], which is combined with supersonic expansion. The molybdenum vaporization is achieved by focusing the second harmonic $(532 \mathrm{~nm})$ of a $5 \mathrm{~ns}$ pulsed $\mathrm{Nd}$ :YAG laser with 5-120 mJ per pulse, depending on the desired cluster species. Due to the high boiling point of molybdenum of $4885 \mathrm{~K}$ [45], relatively high laser pulse energies had to be used. The produced plasma is rapidly thermalized by a precisely timed helium gas pulse of typically $30 \mu$ s, which propagates perpendicularly to the lasers beam path. The gas pulse is produced in the source chamber $\left(10^{-6}-10^{-4} \mathrm{mbar}\right)$ by a piezoelectric valve with a backing pressure of about 20 bar. During thermalization cluster formation occurs. The produced (cluster-)ions are entrained by the helium gas carrier and are accelerated and guided by several electrostatic lenses towards the ultrahigh vacuum (UHV) region, with a pressure in the lower $10^{-10} \mathrm{mbar}$ range without reaction gas. The source gas pulses have no measurable effect on the UHV pressure. The ICR cell is located in the center of the superconducting magnet, where the ions are trapped, mass selected, reacted and detected.

DMDS vapor is introduced into the UHV via a leak valve at a constant background pressure in the range of $(6-8) \times 10^{-9}$ mbar. The liquid sample is degassed by several freeze-pump-thaw cycles. Broadband and single frequency resonant excitation are used to isolate the species of interest. Stable ion signal conditions were obtained for $\mathrm{Mo}_{n}{ }^{+}$, $n=1-3$, and their reactions with DMDS were monitored by taking mass spectra at delays from 0.0 to $25.0 \mathrm{~s}$. Since ion accumulation in the cell takes $2 \mathrm{~s}$, some reaction products are already present at $0 \mathrm{~s}$ reaction delay. Typically, 20 experiment cycles are run at each reaction delay for signal averaging. Kinetic analysis is performed assuming pseudo-first order kinetics. Due to the large number of intermediates and products, only peaks that exceeded a relative intensity of $2 \%$ at any time during the first $4 \mathrm{~s}$ were taken into account for data evaluation, to keep the fits manageable. After calibration of the measured pressures and correcting for ion-gauge sensitivity [46], pressure-independent rate coefficients are obtained as described in detail before [47]. The uncertainty in pressure measurement is the dominant contribution to the experimental error of the rate coefficients, which is typically $25-30 \%$. Branching ratios are more accurate, since they depend only on the error of the pseudo-first order rate coefficients. Their error depends on the overall signal-to-noise level of the experiment and is estimated to $\pm 2-3 \%$ in the present study.

Since natural molybdenum has a broad isotopic distribution, isotopically enriched ${ }^{92}$ Mo (STB Isotope Germany $\mathrm{GmbH}$ ) was used. Metallic powder of $700 \mathrm{mg}{ }^{92} \mathrm{Mo}$ with $\geq 99.9 \%$ enrichment was pressed and sintered into a solid target disk. DMDS ( $\geq 99.0 \%$, Sigma-Aldrich) was used without further purification.

Structure and energetics of relevant species along the reaction path were calculated using density functional theory (DFT), employing the M06-L functional [48] along with the def2TZVP basis set [49]. For species containing molybdenum atoms, various possible conformations were used as a starting point for optimization, with spin multiplicities up to heptuplet. In total, more than 450 initial optimization points of different structure or spin multiplicity were considered for 26 non-trivial molybdenum-containing species studied in the present work. Only the most stable structures are dealt further. The stability of the wavefunction was tested in every local minimum. Frequency calculations were performed to 
verify the absence of imaginary frequencies, zero-point energy is included in all reported energies. No scaling was applied to the calculated frequencies.

See Supporting Information (SI) for the complete parameter matrices containing all calculated absolute reaction rates, as well as optimized structures and benchmarking of the computational method with respect to other DFT functionals and higher-level methods.

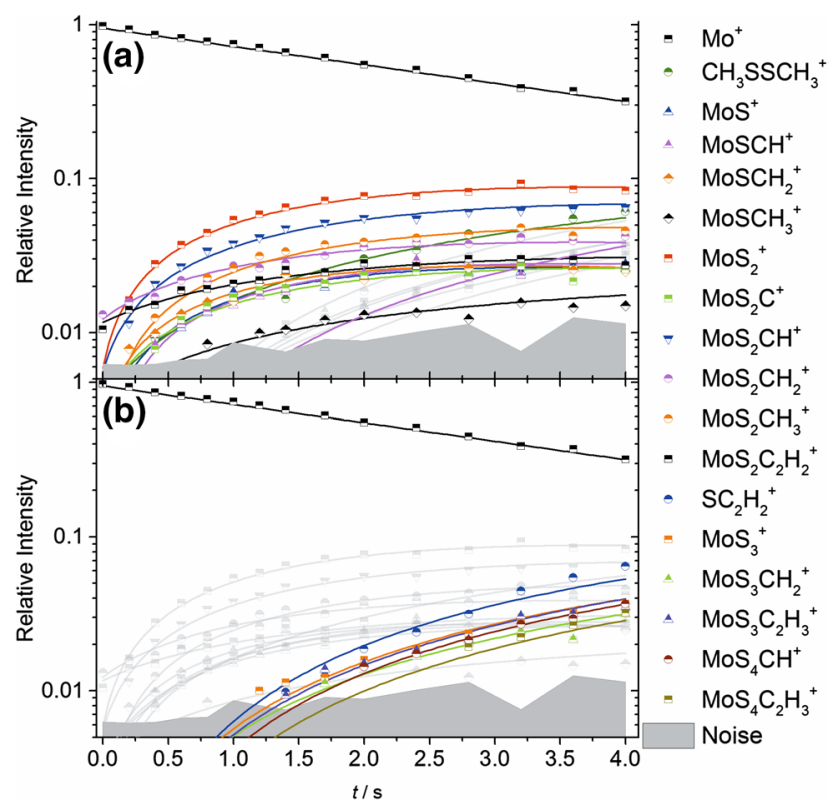

Fig. 1 Kinetic fit of $\mathrm{Mo}^{+}$with DMDS during first $4 \mathrm{~s}$ of the reaction at $p_{\text {DMDS }}=5.9(2) \times 10^{-9}$ mbar. The graph has been split into a primary and $\mathbf{b}$ secondary products

\section{Results and Discussion}

\subsection{Monomer $\mathrm{Mo}^{+}$}

Due to the vast variety of products being formed in competing reactions, the reaction kinetics were fitted only for the first $4.0 \mathrm{~s}$. The kinetic diagram showing the time dependent relative intensities of the parent ion $\left(\mathrm{Mo}^{+}\right)$and its product ions is depicted in Fig. 1. In total 39 reaction channels were used to describe the time profile of the measured data. Since the precursors of secondary and higher order products cannot be unambiguously identified on the basis of the kinetics data, the main focus here lies on the first reaction step. The reactions and rate coefficients for the first reaction step are listed in Table 1. These results are robust with respect to the sequence of secondary and higher-order reactions chosen for the fit. The reaction energies were calculated only for products that, for stoichiometric reasons, can be formed from $\mathrm{Mo}^{+}$and one DMDS molecule.

At the early stage of the reaction, the primary products $\mathrm{MoS}_{2}{ }^{+}, \mathrm{MoS}_{2} \mathrm{CH}^{+}$and $\mathrm{MoS}_{2} \mathrm{CH}_{3}$ are the most dominant, with branching ratios of 24,20 and $12 \%$, respectively (see reactions $1.5,1.7$ and 1.9 in Table 1). The remaining products are produced with branching ratios of 5-8\%. In the kinetic model used for the fit, the DMDS cation is formed by charge transfer from higher order products such as $\mathrm{MoS}^{+}$, $\mathrm{MoSCH}_{2}{ }^{+}$and $\mathrm{MoSCH}_{3}{ }^{+}$(see Table S1). The data at longer times suggest that charge transfer products, in particular $\mathrm{C}_{2} \mathrm{H}_{6} \mathrm{~S}_{2}{ }^{+}$and $\mathrm{C}_{2} \mathrm{H}_{5} \mathrm{~S}^{+}$, are efficiently formed throughout the reaction sequence, most likely from multiple precursors.

Structures of possible association and reaction products are shown in Fig. 2a. When $\mathrm{Mo}^{+}$and $\mathrm{CH}_{3} \mathrm{SSCH}_{3}$ interact,
Table 1 Rate coefficients and reaction energies for the first step of the suggested reaction sequence of $\mathrm{Mo}^{+}$with DMDS during the first $4.0 \mathrm{~s}$

\begin{tabular}{lllrc}
\hline & Products & $k_{\mathrm{abs}} / 10^{-10} \mathrm{~cm}^{3} \mathrm{~s}^{-1}$ & $\Delta E / \mathrm{eV}$ & $\begin{array}{c}\text { Branching } \\
\text { ratio (\%) }\end{array}$ \\
\hline$(1.1)$ & ${ }^{4} \mathrm{MoS}^{+}+\mathrm{CH}_{3} \mathrm{SCH}_{3}$ & 1.6 & -1.30 & 7 \\
$(1.2)$ & ${ }^{5} \mathrm{MoSCH}^{+}+\mathrm{CH}_{4}+\mathrm{SH}$ & 1.4 & 0.01 & 6 \\
$(1.3)$ & ${ }^{4} \mathrm{MoSCH}_{2}{ }^{+}+\mathrm{CH}_{3} \mathrm{SH}$ & 1.6 & -1.58 & 7 \\
$(1.4)$ & ${ }^{3} \mathrm{MoSCH}_{3}{ }^{+}+\mathrm{CH}_{3} \mathrm{~S}$ & 1.0 & -1.02 & 5 \\
$(1.5)$ & ${ }^{2} \mathrm{MoS}_{2}{ }^{+}+\mathrm{C}_{2} \mathrm{H}_{6}$ & 5.2 & -3.40 & 24 \\
& ${ }^{2} \mathrm{MoS}_{2}{ }^{+}+2 \mathrm{CH}_{3}$ & & 0.34 & \\
$(1.6)$ & ${ }^{4} \mathrm{MoS}_{2} \mathrm{C}^{+}+\mathrm{CH}_{4}+\mathrm{H}_{2}$ & 1.1 & -1.99 & 5 \\
$(1.7)$ & ${ }^{1} \mathrm{MoS}_{2} \mathrm{CH}^{+}+\mathrm{CH}_{4}+\mathrm{H}$ & 4.3 & -0.80 & 20 \\
& ${ }^{1} \mathrm{MoS}_{2} \mathrm{CH}^{+}+\mathrm{CH}_{3}+\mathrm{H}_{2}$ & & -0.63 & \\
$(1.8)$ & ${ }^{2} \mathrm{MoS}_{2} \mathrm{CH}_{2+}+\mathrm{CH}_{4}$ & 1.2 & -3.95 & 5 \\
$(1.9)$ & ${ }^{1} \mathrm{MoS}_{2} \mathrm{CH}_{3}{ }^{+}+\mathrm{CH}_{3}$ & 2.6 & -2.01 & 12 \\
$(1.10)$ & ${ }^{2} \mathrm{MoS}_{2} \mathrm{C}_{2} \mathrm{H}_{2}+2 \mathrm{H}_{2}$ & 1.8 & -1.87 & 8 \\
\hline
\end{tabular}

The uncertainty for the rate coefficients has been estimated to $27 \%$. For the branching ratios, an error of $\pm 2 \%$ is assumed. Reaction energies $\Delta E$ were calculated at the M06-L/def2TZVP level; composition of neutral product molecules and spin multiplicities for Mo-containing species (denoted as superscripts) were deduced from quantum chemical calculations 
there is up to $4.7 \mathrm{eV}$ of energy released (as calculated at the M06-L/def2TZVP level of theory). This energy is redistributed among the internal degrees of freedom of the cluster and leads to dissociation of various bonds, leading to the observed reaction products. The high reaction energy also explains why the association product is not observed among the reactions products, since a large number of strongly exothermic reaction channels make radiative association [50] impossible. The majority of dissociation reactions are calculated to be substantially exothermic; however, the fastest reactions are not necessarily the most exothermic ones. This might be rationalized by kinetic effects, or entropic barriers might prevent the ion from reorganization. At the same time, different neutral reaction products might be formed than the ones assumed in Table 1, e.g. $2 \mathrm{CH}_{3}$ instead of $\mathrm{C}_{2} \mathrm{H}_{6}$, leading

\section{(a) $\mathrm{Mo}^{+}+\mathrm{CH}_{3} \mathrm{SSCH}_{3} \rightarrow\left[\mathrm{Mo}^{-\mathrm{CH}_{3}} \mathrm{SSCH}_{3}\right]^{+}$}
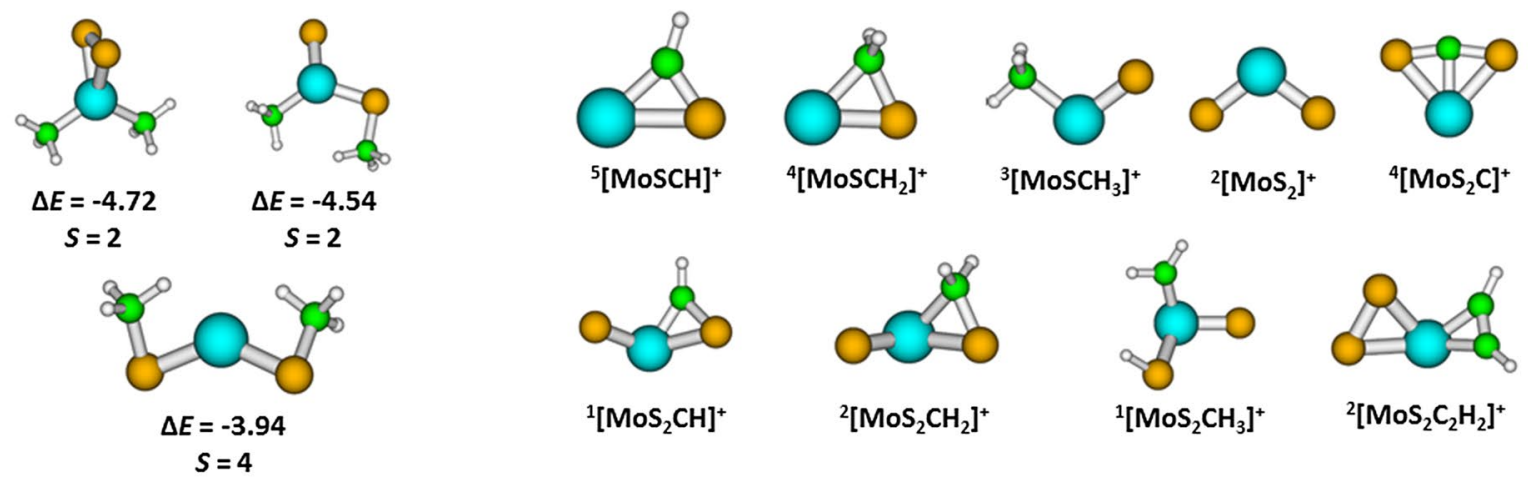

(b) $\mathrm{Mo}_{2}{ }^{+}+\mathrm{CH}_{3} \mathrm{SSCH}_{3} \rightarrow\left[\mathrm{Mo}_{2} \cdot \mathrm{CH}_{3} \mathrm{SSCH}_{3}\right]^{+}$

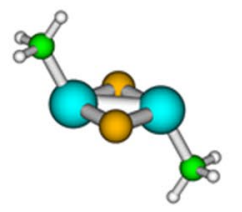

$\Delta E=-5.93$
$S=4$
$\Delta E=-3.96$
$S=2$

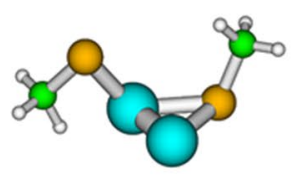

(c) $\mathrm{Mo}_{3}{ }^{+}+\mathrm{CH}_{3} \mathrm{SSCH}_{3} \rightarrow\left[\mathrm{Mo}_{3} \cdot \mathrm{CH}_{3} \mathrm{SSCH}_{3}\right]^{+}$
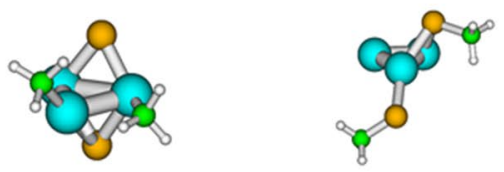

$\Delta E=-7.04$

$\Delta E=-3.93$

$S=2$

(d)

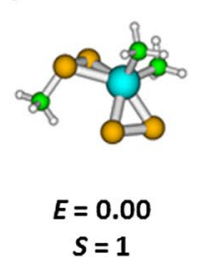

$\left[\mathrm{MoS}_{4} \mathrm{C}_{3} \mathrm{H}_{9}\right]^{+}$
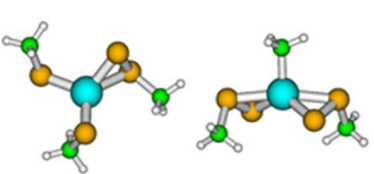
$E=0.09$
$S=3$
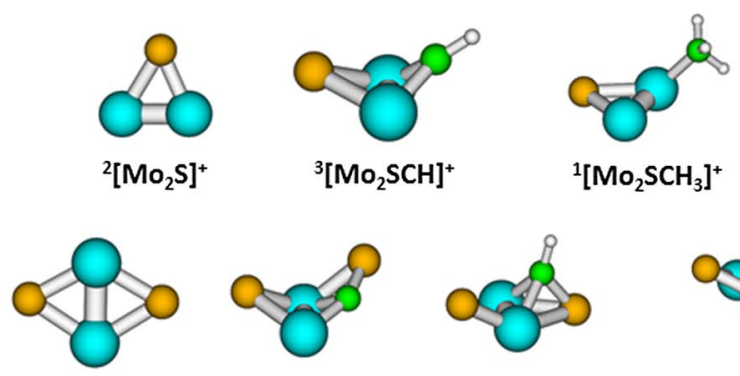

${ }^{2}\left[\mathrm{Mo}_{2} \mathrm{~S}_{2}\right]^{+}$

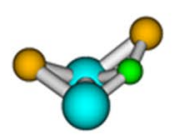

${ }^{4}\left[\mathrm{Mo}_{2} \mathrm{~S}_{2} \mathrm{C}\right]^{+}$

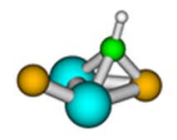

${ }_{3}^{3}\left[\mathrm{Mo}_{2} \mathrm{~S}_{2} \mathrm{CH}\right]^{+}$

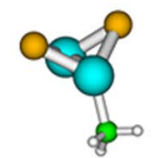

${ }^{1}\left[\mathrm{Mo}_{2} \mathrm{~S}_{2} \mathrm{CH}_{3}\right]^{+}$
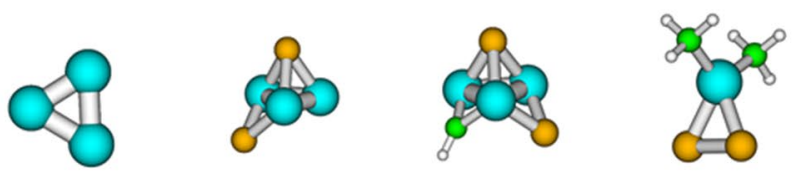

${ }^{2} \mathrm{Mo}_{3}{ }^{+}$

${ }^{2}\left[\mathrm{Mo}_{3} \mathrm{~S}_{2}\right]^{+}$

${ }^{3}\left[\mathrm{Mo}_{3} \mathrm{~S}_{2} \mathrm{CH}\right]^{+}$

${ }^{3} \mathrm{MoS}_{2} \mathrm{C}_{2} \mathrm{H}_{6}$

\section{$\left[\mathrm{MoS}_{5} \mathrm{C}_{2} \mathrm{H}_{6}\right]^{+}$}
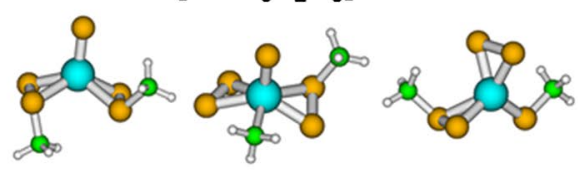
$E=0.00$
$S=2$
$E=0.37$
$S=2$
$E=0.47$
$S=2$
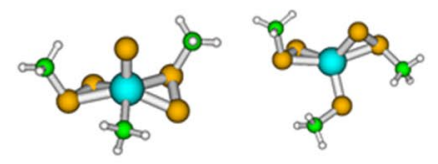
$E=0.00$
$S=1$

$E=0.56$

their relative energy $E$ (in $\mathrm{eV}$ ). All structures were optimized at the M06-L/def2TZVP level of theory, spin multiplicities $S$ are given for each ion. Color code: molybdenum—blue; sulfur-orange; carbongreen; hydrogen-white
Fig. 2 a-c Left: initial complexes obtained after the reaction of $\mathrm{Mo}_{n}{ }^{+}$and $\mathrm{CH}_{3} \mathrm{SSCH}_{3}, n=1-3$, along with energy $\Delta E$ (in eV) relative to the separated reactants. Right: ions obtained after dissociation of the initial complex as included in Tables 1, 2, 3 as well as neutral $\mathrm{MoS}_{2} \mathrm{C}_{2} \mathrm{H}_{6}$. d Selected ions arising during secondary reactions and 
to less exothermic reactions. There is one reaction that is slightly endothermic (reaction 1.2, $\Delta E=0.01$ ) where we might expect that the excess energy is supplied by the kinetic energy of the trapped ions.

From a structural perspective, molybdenum tends to form as many bonds with heavy atoms as possible, as shown also in previous studies on charged and neutral $\mathrm{Mo}_{x} \mathrm{~S}_{y}$ clusters $[18,19,51]$. Already for the association product, the structure containing two Mo-C and two Mo-S bonds was found to be the most stable one (see Fig. 2a). This is also true for ions produced in subsequent reactions that form as many bonds of molybdenum with heavy atoms as possible (see below). There were, on the other hand, no structures with the metal center inserting into $\mathrm{C}-\mathrm{H}$ bonds found among the most stable isomers. This is perfectly in line with studies by Armentrout on the activation of alkanes by $\mathrm{Mo}^{+}$, where only endothermic reactions were observed [52-54].

A qualitative analysis of the mass spectra for reaction delay until $t_{r}=20.0 \mathrm{~s}$ reveals that these products continue to react with DMDS until the final products are formed. The molybdenum containing products are shown in Fig. 3, where the most dominant ones are $\mathrm{MoS}_{5} \mathrm{C}_{2} \mathrm{H}_{6}{ }^{+}, \mathrm{MoS}_{4} \mathrm{C}_{3} \mathrm{H}_{9}{ }^{+}$ and $\mathrm{MoS}_{5} \mathrm{C}_{3} \mathrm{H}_{9}{ }^{+}$. It is worth mentioning that neither pure $\mathrm{MoS}_{\mathrm{x}}{ }^{+}$nor $\mathrm{MoC}_{\mathrm{x}} \mathrm{H}_{\mathrm{y}}{ }^{+}$species were present as final products. Combining the general reaction pattern with theoretical calculations on geometry optimization at the M06-L/ def2TZVP level suggests the formation of up to five Mo-S bonds together with Mo-C bonds, see Fig. 2d. This may be expected, since molybdenum is known to form a rich variety of sulfides [45]. However, the most intense final product is the charge transfer product $\mathrm{SC}_{2} \mathrm{H}_{5}{ }^{+}$. Other intense charge transfer products are $\mathrm{S}_{2} \mathrm{C}_{2} \mathrm{H}_{6}{ }^{+}, \mathrm{S}_{3} \mathrm{C}_{3} \mathrm{H}_{9}{ }^{+}, \mathrm{SC}_{2} \mathrm{H}_{3}{ }^{+}$and $\mathrm{S}_{2} \mathrm{C}_{3} \mathrm{H}_{7}^{+}$; their intensities are 88, 53, 41 and $20 \%$, respectively, relative to $\mathrm{SC}_{2} \mathrm{H}_{5}{ }^{+}$with $100 \%$.

\subsection{Dimer $\mathrm{MO}_{2}^{+}$}

Again, due to the vast variety of simultaneous reactions with different intermediates reacting through competing reaction channels, only the first $4.0 \mathrm{~s}$ of the reaction were analyzed with a kinetics fit. The kinetic model was developed iteratively by choosing stoichiometrically allowed and chemically reasonable reaction pathways and testing the quality of the fit. In Fig. 4 the time dependent relative intensities of the parent and product ions are shown. Due to the many intermediates which had to be taken into account, the graph is split in primary and higher order products. The primary reactions are listed in Table 2. A total of 46 different reaction channels were used in the kinetic model. At this high number of different reaction channels, the chosen model is not the only possibility, and secondary reactions cannot be assigned unambiguously. Therefore, only the first step, $\mathrm{Mo}_{2}{ }^{+}$ $+\mathrm{CH}_{3} \mathrm{SSCH}_{3}$, is discussed in more detail. The reactions 2.1, 2.4 and 2.6 are dominant, consistent with the tendency of molybdenum to directly extract sulfur from DMDS. All reactions included in Table 2 are again calculated to be exothermic.

The addition of $\mathrm{CH}_{3} \mathrm{SSCH}_{3}$ to $\mathrm{Mo}_{2}{ }^{+}$is again considerably exothermic (up to $-5.9 \mathrm{eV}$, see Fig. 2b). DMDS tends to dissociate on the ion, forming a rhombic $\mathrm{Mo}_{2} \mathrm{~S}_{2}$ core with $\mathrm{CH}_{3}$ groups attached to Mo atoms. The product ions form a high number of Mo-S and Mo-C bonds, similar to the case of $\mathrm{Mo}^{+}$. Predicted structural patterns are close to the ones calculated for neutral $\mathrm{Mo}_{x} \mathrm{~S}_{y}$ gas phase compounds [18].

For reaction delays higher than $4.0 \mathrm{~s}$, the acquired mass spectra were analyzed qualitatively, revealing that after a reaction time of approximately $t_{r}=19.0 \mathrm{~s}$ the dimer is completely converted to the products shown in Fig. S1. Clearly the most abundant products are $\mathrm{Mo}_{2} \mathrm{~S}_{6} \mathrm{C}_{3} \mathrm{H}_{9}{ }^{+}, \mathrm{Mo}_{2} \mathrm{~S}_{7} \mathrm{C}_{3} \mathrm{H}_{9}{ }^{+}$ and $\mathrm{Mo}_{2} \mathrm{~S}_{8} \mathrm{C}_{3} \mathrm{H}_{9}{ }^{+}$. Again, no pure $\mathrm{Mo}_{\mathrm{z}} \mathrm{S}_{\mathrm{x}}{ }^{+}$nor $\mathrm{Mo}_{\mathrm{z}} \mathrm{C}_{\mathrm{x}} \mathrm{H}_{\mathrm{y}}{ }^{+}$ were found as final products. In the low mass region,
Table 2 Rate coefficients for the suggested reaction sequence of $\mathrm{Mo}_{2}{ }^{+}$with DMDS during the first $4.0 \mathrm{~s}$ of the reaction

\begin{tabular}{llllc}
\hline & Products & $k_{\text {abs }} / 10^{-10} \mathrm{~cm}^{3} \mathrm{~s}^{-1}$ & $\Delta E / \mathrm{eV}$ & $\begin{array}{c}\text { Branching } \\
\text { ratio (\%) }\end{array}$ \\
\hline$(2.1)$ & ${ }^{2} \mathrm{Mo}_{2} \mathrm{~S}^{+}+\mathrm{CH}_{3} \mathrm{SCH}_{3}$ & 2.7 & -2.10 & 23 \\
$(2.2)$ & ${ }^{3} \mathrm{Mo}_{2} \mathrm{SCH}^{+}+\mathrm{CH}_{4}+\mathrm{SH}$ & 1.2 & -0.83 & 10 \\
$(2.3)$ & ${ }^{1} \mathrm{Mo}_{2} \mathrm{SCH}_{3}{ }^{+} \mathrm{CH}_{3} \mathrm{~S}$ & 0.8 & -1.39 & 7 \\
$(2.4)$ & ${ }^{2} \mathrm{Mo}_{2} \mathrm{~S}_{2}{ }^{+}+\mathrm{C}_{2} \mathrm{H}_{6}$ & 1.7 & -4.56 & 14 \\
& ${ }^{2} \mathrm{Mo}_{2} \mathrm{~S}_{2}{ }^{+}+2 \mathrm{CH}_{3}$ & & -0.81 & \\
$(2.5)$ & ${ }^{4} \mathrm{Mo}_{2} \mathrm{~S}_{2} \mathrm{C}^{+}+\mathrm{CH}_{4}+\mathrm{H}_{2}$ & 1.2 & -2.83 & 10 \\
$(2.6)$ & ${ }^{3} \mathrm{Mo}_{2} \mathrm{~S}_{2} \mathrm{CH}^{+}+\mathrm{CH}_{4}+\mathrm{H}$ & 2.6 & -1.23 & 22 \\
& ${ }^{3} \mathrm{Mo}_{2} \mathrm{~S}_{2} \mathrm{CH}^{+}+\mathrm{CH}_{3}+\mathrm{H}_{2}$ & & -1.06 & \\
$(2.7)$ & ${ }^{1} \mathrm{Mo}_{2} \mathrm{~S}_{2} \mathrm{CH}_{3}{ }^{+}+\mathrm{CH}_{3}$ & 1.4 & -3.53 & 13 \\
\hline
\end{tabular}

The uncertainty for the rate coefficients has been estimated to $29 \%$. For the branching ratios, an error of $\pm 2 \%$ is assumed. Reaction energies $\Delta E$ were calculated at the M06-L/def2TZVP level; composition of neutral product molecules and spin multiplicities for Mo-containing species (denoted as superscripts) were deduced from quantum chemical calculations 
Table 3 Rate coefficients for the suggested reaction sequence of $\mathrm{Mo}_{3}{ }^{+}$with DMDS during the first $4.0 \mathrm{~s}$ of the reaction

\begin{tabular}{|c|c|c|c|c|}
\hline & Products & $k_{\mathrm{abs}} / 10^{-10} \mathrm{~cm}^{3} \mathrm{~s}^{-1}$ & $\Delta E / \mathrm{eV}$ & $\begin{array}{l}\text { Branch- } \\
\text { ing ratio } \\
(\%)\end{array}$ \\
\hline$(3.1)$ & ${ }^{2} \mathrm{Mo}_{2}{ }^{+}+{ }^{3} \mathrm{MoS}_{2} \mathrm{C}_{2} \mathrm{H}_{6}$ & 5.3 & -0.98 & 47 \\
\hline$(3.2)$ & $\begin{array}{l}{ }^{2} \mathrm{Mo}_{3} \mathrm{~S}_{2}{ }^{+}+\mathrm{C}_{2} \mathrm{H}_{6} \\
{ }^{2} \mathrm{Mo}_{3} \mathrm{~S}_{2}{ }^{+}+2 \mathrm{CH}_{3}\end{array}$ & 2.0 & $\begin{array}{l}-6.23 \\
-2.48\end{array}$ & 18 \\
\hline (3.3) & ${ }^{3} \mathrm{Mo}_{3} \mathrm{~S}_{2} \mathrm{CH}^{+}+\mathrm{CH}_{4}+\mathrm{H}$ & 3.7 & -4.19 & 35 \\
\hline
\end{tabular}

The uncertainty for the rate coefficients has been estimated to $29 \%$. For the branching ratios, an error of $\pm 3 \%$ is assumed. Reaction energies $\Delta E$ were calculated at the M06-L/def2TZVP level; composition of neutral product molecules and spin multiplicities for Mo-containing species (denoted as superscripts) were deduced from quantum chemical calculations

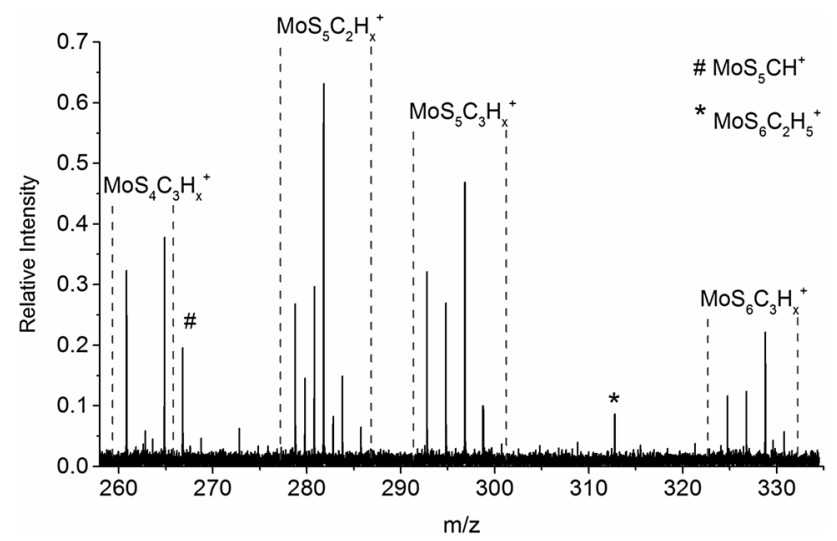

Fig. 3 Mass spectrum of $\mathrm{Mo}^{+}$with DMDS after a reaction delay of $20.0 \mathrm{~s}$ showing the final products of the reaction $\left(p_{\text {DMDS }}=5.9(2) \times 10^{-9} \mathrm{mbar}\right)$. Intensities are given relative to the most abundant product $\mathrm{SC}_{2} \mathrm{H}_{5}{ }^{+}$

charge transfer products were found. These were identified as $\mathrm{SC}_{2} \mathrm{H}_{5}{ }^{+}, \mathrm{S}_{2} \mathrm{C}_{2} \mathrm{H}_{6}{ }^{+}$(ionized DMDS) and $\mathrm{S}_{3} \mathrm{C}_{3} \mathrm{H}_{9}{ }^{+}$; their intensities relative to the most intensive $\mathrm{Mo}_{2} \mathrm{~S}_{8} \mathrm{C}_{3} \mathrm{H}_{9}{ }^{+}$peak are 29,19 and $11 \%$, respectively.

\subsection{Trimer $\mathrm{Mo}_{3}{ }^{+}$}

For the first $4.0 \mathrm{~s}$, the reaction proceeds smoothly, as shown in Fig. 5. Since $\mathrm{Mo}_{2}{ }^{+}$is a product of the reaction, as shown in the mass spectrum in Fig S2, a large number of species can be observed as secondary products. Interestingly, two oxide species $\mathrm{Mo}_{2} \mathrm{O}^{+}$and $\mathrm{Mo}_{3} \mathrm{~S}_{2} \mathrm{O}^{+}$are observed, suggesting that some of the species present might be capable of dehydrogenating water, which is likely to be present in traces in the vacuum system. The kinetic fit, Fig. 5, shows that the oxides are not primary products of $\mathrm{Mo}_{3}{ }^{+}+\mathrm{CH}_{3} \mathrm{SSCH}_{3}$. The first step of the reaction kinetics was modelled as shown in Table 3. Calculated reaction energies are all exothermic.

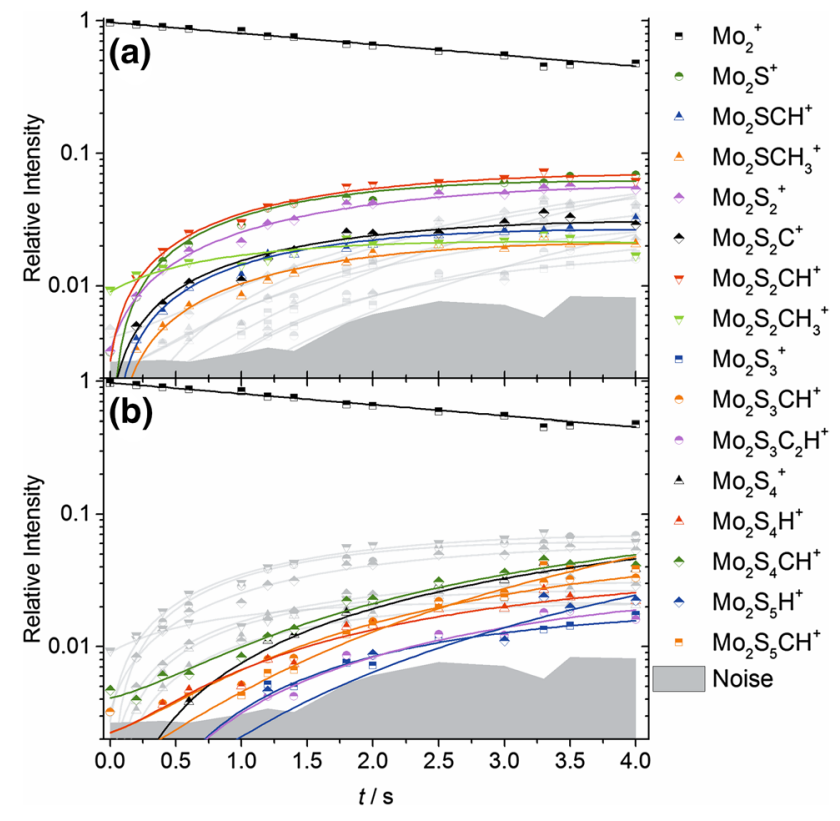

Fig. 4 Kinetic fit of $\mathrm{Mo}_{2}{ }^{+}$with DMDS during the first $4.0 \mathrm{~s}$ of the reaction at $p_{\text {DMDS }}=7.6(7) \times 10^{-9}$ mbar. For the sake of clarity, the graph has been split in products containing up to two (a) or up to five (b) sulfur atoms respectively

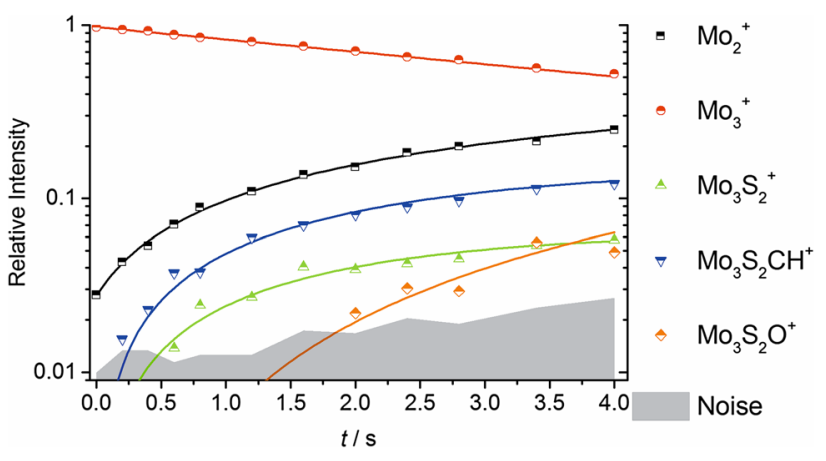

Fig. 5 Kinetic fit of $\mathrm{Mo}_{3}{ }^{+}$with DMDS during first $4.0 \mathrm{~s}$ of the reaction at $p_{\text {DMDS }}=6.8(5) \times 10^{-9} \mathrm{mbar}$

Molybdenum trimer $\mathrm{Mo}_{3}{ }^{+}$is predicted to be cyclic, in agreement with previous calculations on neutral systems [18]. The trimer unit is also kept during optimization for complexes with sulfur or carbon atoms, with the association product having a sandwich structure with a $\mathrm{Mo}_{3} \mathrm{~S}_{2}$ core and two $\mathrm{CH}_{3}$ groups attached to Mo atoms, analogous to the association product of $\mathrm{Mo}_{2}{ }^{+}$and DMDS (see Fig. 2c), with the reaction energy of $-7.0 \mathrm{eV}$. It is interesting to note that the only reaction that does not produce a $\mathrm{Mo}_{3}$-containing ion, reaction 3.1 resulting in $\mathrm{Mo}_{2}{ }^{+}+\mathrm{CH}_{3} \mathrm{Mo}\left(\mathrm{S}_{2}\right) \mathrm{CH}_{3}$, is with $\Delta E=-0.98 \mathrm{eV}$ only mildly exothermic, but has almost $50 \%$ branching ratio. This indicates that during the formation of 
the association product, the initial insertion of a Mo center into the $\mathrm{S}-\mathrm{S}$ bond releases sufficient energy to liberate $\mathrm{Mo}_{2}{ }^{+}$.

Interestingly, no charge transfer products were found in the acquired mass spectra. This might be due to the relatively high noise level in the $\mathrm{Mo}_{3}{ }^{+}$experiment, which leads to small intensities of secondary products of $\mathrm{Mo}_{2}{ }^{+}$in the first $4 \mathrm{~s}$ of the reaction, below the noise level.

\section{Conclusions}

Despite the vast variety of product ions forming, the early stage of each reaction was analyzed for all molybdenum cluster cations examined. Reasonable reaction schemes with realistic reaction rates in the order of $10^{-10} \mathrm{~cm}^{3} \mathrm{~s}^{-1}$ were found. Charge transfer reactions forming mixed $\mathrm{S}_{\mathrm{x}} \mathrm{C}_{\mathrm{y}} \mathrm{H}_{\mathrm{z}}^{+}$ clusters were observed only for the monomer and dimer in later stages of the reaction; in fact, charge transfer product ions became the dominant products in the monomer kinetics after longer times. At higher reaction delays, the dominant molybdenum containing product ions had the form $\mathrm{Mo}_{x} \mathrm{~S}_{y}\left(\mathrm{CH}_{3}\right)_{z}^{+}$with $x=1,2, y>x$ and $z=2,3$. Supported by theoretical calculations, it can be assumed that these products consist of two or three methyl groups binding on the sulfided molybdenum cluster. The trimer was found to be relatively unstable, since a dissociative reaction channel was observed producing the fragment ion $\mathrm{Mo}_{2}{ }^{+}$at a high rate of $(5.3 \pm 1.5) \times 10^{-10} \mathrm{~cm}^{3} \mathrm{~s}^{-1}$. Albeit not being final products, pure $\mathrm{Mo}_{\mathrm{x}} \mathrm{S}_{\mathrm{y}}^{+}$product ions were observed for all examined species, illustrating the strong tendency of molybdenum to form sulfides by direct extraction of sulfur from DMDS.

In accordance with literature [16], the high sulfidation potential of DMDS can be confirmed. However, also a high yield of $\mathrm{C}_{\mathrm{x}} \mathrm{H}_{\mathrm{y}}$ species incorporated in the product clusters is observed. According to the calculated energetics from the literature [16], the binding energy of $\mathrm{CH}_{y}$ species incorporated in $\mathrm{MoS}_{2}$ increases from $\mathrm{C}$ via $\mathrm{CH}$ and $\mathrm{CH}_{2}$ to $\mathrm{CH}_{3}$. This trend is qualitatively reflected in the product distribution, where $\mathrm{Mo}_{\mathrm{p}} \mathrm{S}_{\mathrm{q}} \mathrm{C}_{\mathrm{x}}{ }^{+}$species are very rare.

Acknowledgements This project is supported by the Klima- und Energiefonds, administered by the FFG under Project No. 853639, and put into effect in the framework of the program "ENERGIE DER ZUKU$N F T$ ". We thank Ramona Thalinger for preparing the molybdenum targets. M.O. acknowledges support through the Lise Meitner Programme of the Austrian Science Fund (FWF), Project No. M2001-NBL. The computational results presented have been achieved using the HPC infrastructure LEO of the University of Innsbruck. Open access funding provided by University of Innsbruck and Medical University of Innsbruck.

Open Access This article is distributed under the terms of the Creative Commons Attribution 4.0 International License (http://creativeco mmons.org/licenses/by/4.0/), which permits unrestricted use, distribution, and reproduction in any medium, provided you give appropriate credit to the original author(s) and the source, provide a link to the Creative Commons license, and indicate if changes were made.

\section{References}

1. Karunadasa HI, Montalvo E, Sun Y, Majda M, Long JR, Chang CJ (2012) Science 335:698-702

2. Jaramillo TF, Jørgensen KP, Bonde J, Nielsen JH, Horch S, Chorkendorff I (2007) Science 317:100-102

3. Kibsgaard J, Jaramillo TF, Besenbacher F (2014) Nat Chem $6: 248-253$

4. Huang Z, Luo W, Ma L, Yu M, Ren X, He M, Polen S, Click K, Garrett B, Lu J, Amine K, Hadad C, Chen W, Asthagiri A, Wu Y (2015) Angew Chem Int Ed 54:15181-15185

5. Garrett BR, Polen SM, Pimplikar M, Hadad CM, Wu Y (2017) J Am Chem Soc 139:4342-4345

6. Garrett BR, Click KA, Durr CB, Hadad CM, Wu Y (2016) J Am Chem Soc 138:13726-13731

7. Garrett BR, Polen SM, Click KA, He M, Huang Z, Hadad CM, Wu Y (2016) Inorg Chem 55:3960-3966

8. Toyoda T, Minami T, Qian EW (2013) Energy Fuels 27:3769-3777

9. Liu C, Liu P (2015) ACS Catal 5:1004-1012

10. Okamoto Y, Hioka K, Arakawa K, Fujikawa T, Ebihara T, Kubota T (2009) J Catal 268:49-59

11. Topsøe H, Clausen BS (2007) Catal Rev 26:395-420

12. Topsøe H, Clausen BS, Massoth FE (1996) Hydrotreating catalysis. In: Anderson JR, Boudart M (eds) Catalysis. Springer, Berlin, pp 1-269

13. Wang X, Fang H, Zhao Z, Duan A, Xu C, Chen Z, Zhang M, Du P, Song S, Zheng P, Chi K (2015) RSC Adv 5:99706-99711

14. Levita G, Righi MC (2017) ChemPhysChem 18:1475-1480

15. Texier S, Berhault G, Pérot G, Harlé V, Diehl F (2004) J Catal 223:404-418

16. Tuxen A, Gøbel H, Hinnemann B, Li Z, Knudsen KG, Topsøe H, Lauritsen JV, Besenbacher F (2011) J Catal 281:345-351

17. McBride KL, Head JD (2009) Int J Quantum Chem 109:3570-3582

18. Murugan P, Kumar V, Kawazoe Y, Ota N (2007) J Phys Chem A 111:2778-2782

19. Kumar CA, Saha A, Raghavachari K (2017) J Phys Chem A 121:1760-1767

20. Kretzschmar I, Fiedler A, Harvey JN, Schröder D, Schwarz H (1997) J Phys Chem A 101:6252-6264

21. González-Navarrete P, Schlangen M, Wu X-N, Schwarz H (2016) Chem Eur J 22:3077-3083

22. González-Navarrete P, Schlangen M, Schwarz H (2017) Struct Chem 28:403-413

23. Kretzschmar I, Schröder D, Schwarz H, Armentrout PB (2003) Int J Mass Spectrom 228:439-456

24. Rodgers MT, Armentrout PB (2000) Mass Spectrom Rev 19:215-247

25. Sievers MR, Armentrout PB (1998) J Phys Chem A 102:10754-10762

26. Fielicke A, Rademann K (2002) Chem Phys Lett 359:360-366

27. Ferrari P, Vanbuel J, Tam NM, Nguyen MT, Gewinner S, Schöllkopf W, Fielicke A, Janssens E (2017) Chem Eur J 23:4120-4127

28. Koyanagi GK, Xu J, Bohme DK (2008) Chem Phys Lett 450:228-231

29. Cheng P, Koyanagi GK, Bohme DK (2007) J Phys Chem A 111:8561-8573

30. Cheng P, Koyanagi GK, Bohme DK (2006) J Phys Chem A 110:2718-2728

31. Koyanagi GK, Caraiman D, Blagojevic V, Bohme DK (2002) J Phys Chem A 106:4581-4590

32. Lavrov VV, Blagojevic V, Koyanagi GK, Orlova G, Bohme DK (2004) J Phys Chem A 108:5610-5624 
33. Blagojevic V, Orlova G, Bohme DK (2005) J Am Chem Soc 127:3545-3555

34. Berg C, Beyer M, Achatz U, Joos S, Niedner-Schatteburg G, Bondybey VE (1998) J Chem Phys 108:5398-5403

35. Balteanu I, Achatz U, Balaj O, Fox BS, Beyer MK, Bondybey VE (2003) Int J Mass Spectrom 229:61-65

36. van der Linde C, Hemmann S, Höckendorf RF, Balaj OP, Beyer MK (2013) J Phys Chem A 117:1011-1020

37. Balaj OP, Balteanu I, Roßteuscher TTJ, Beyer MK, Bondybey VE (2004) Angew Chem Int Ed 43:6519-6522

38. Wesendrup R, Schröder D, Schwarz H (1994) Angew Chem Int Ed 33:1174-1176

39. Bohme DK, Schwarz H (2005) Angew Chem Int Ed 44:2336-2354

40. Bondybey VE, Beyer MK (2002) Int Rev Phys Chem 21:277-306

41. Höckendorf RF, Balaj OP, van der Linde C, Beyer MK (2010) Phys Chem Chem Phys 12:3772-3779

42. Bondybey VE, English JH (1981) J Chem Phys 74:6978-6979

43. Dietz TG, Duncan MA, Powers DE, Smalley RE (1981) J Chem Phys 74:6511-6512
44. Berg C, Schindler T, Niedner-Schatteburg G, Bondybey VE (1995) J Chem Phys 102:4870-4884

45. Christen HR, Meyer G (1995) Allgemeine und anorganische Chemie, Band 2, 1st edn. Salle, Frankfurt am Main, Sauerländer, Aarau, Frankfurt am Main, Salzburg

46. Bartmess JE, Georgiadis RM (1983) Vacuum 33:149-153

47. Akhgarnusch A, Höckendorf RF, Beyer MK (2015) J Phys Chem A 119:9978-9985

48. Zhao Y, Truhlar DG (2006) J Chem Phys 125:194101

49. Weigend F, Ahlrichs R (2005) Phys Chem Chem Phys 7:3297-3305

50. Dunbar RC (1997) Int J Mass Spectrom Ion Processes 160:1-16

51. Lightstone JM, Mann HA, Wu M, Johnson PM, White MG (2003) J Phys Chem B 107:10359-10366

52. Armentrout PB (2007) Organometallics 26:5473-5485

53. Armentrout PB (2007) Organometallics 26:5486-5500

54. Armentrout PB (2006) J Phys Chem A 110:8327-8338 